\title{
MODELS TO ESTIMATE PHYTOMASS ACCUMULATION OF HYDROPONIC LETTUCE
}

\author{
Sidinei José Lopes; Durval Dourado Neto²*; Paulo Augusto Manfron; Luís Renato Jasniewicz ${ }^{1}$ \\ ${ }^{1}$ UFSM - Depto. de Fitotecnia, 97105-900 - Santa Maria, RS - Brasil. \\ ${ }^{2}$ USP/ESALQ - Depto. de Produção Vegetal, C.P. 9 - 13418-900 - Piracicaba, SP - Brasil. \\ *Corresponding author <dourado@esalq.usp.br>
}

\begin{abstract}
The protected and hydroponics cultivation are increasing in Brazil, demanding a better knowledge of crop performance in this environment. Plant dry matter accumulation as a function of solar radiation, temperature, relative humidity and other weather parameters in greenhouse is different when compared with field cultivation. With the purpose of proposing models to characterize the temporal variation of leaf and total dry matter production of hydroponics-grown lettuce (Lactuca sativa L.) and to determine the flowering period and the maximum dry matter accumulation rate as a function of plant relative development (relative degree-days), solar radiation and effective thermal index, two experiments (Spring and Autumn) were carried out in the greenhouse, at Santa Maria, Rio Grande do Sul State, Brazil. Growth and development models are useful in obtaining basic information on the plant $\times$ environment interactions, maximizing the use of resources in greenhouse, as well as, to define the best form of crop management. The cultivar Vera was chosen as function of its earliness. Models were proposed to estimate the temporal variation of dry matter accumulation, where the best results for relative development were obtained using effective degree-days, characterizing the importance of the air temperature for the vegetative phase and the solar radiation for the reproductive. The yield and quality of the lettuce seeds evidenced a high potential of hydroponics technique.
\end{abstract}

Key words: modeling, dry matter, plastic-greenhouse

\section{MODELOS PARA ESTIMAR O ACÚMULO DE FITOMASSA DE ALFACE EM HIDROPONIA}

\begin{abstract}
RESUMO: O cultivo protegido e o cultivo hidropônico de plantas estão sendo cada vez mais utilizados no Brasil, exigindo maior conhecimento sobre as respostas das plantas nesses ambientes. O acúmulo de massa seca de plantas em cultivo protegido é função da radiação solar, temperatura, umidade e outros elementos climáticos, e é diferente quando comparado com o cultivo a campo. Com o objetivo de propor modelos para caracterizar a variação temporal na massa seca de folhas e total da cultura de alface hidropônica, bem como determinar a época de florescimento e de máxima taxa de acúmulo de matéria seca em função do desenvolvimento relativo da cultura (graus-dia relativo), radiação solar e graus-dia efetivo, dois experimentos (primavera e outono) foram conduzidos em ambiente protegido em Santa Maria, RS. Modelos de crescimento e desenvolvimento são úteis na obtenção de informações básicas das interações planta $\times$ ambiente, maximizando o uso de recursos em ambiente protegido, bem como, para definir a melhor forma de manejo da cultura. Foi utilizada a variedade Vera, por não florescer precocemente. Foram propostos modelos para estimar a variação temporal de massa seca, sendo o melhor ajuste quando o desenvolvimento relativo foi obtido por graus-dia efetivo, caracterizando a maior importância da temperatura do ar na fase vegetativa e da radiação solar na fase reprodutiva. A produção e a qualidade de sementes de alface indicam um alto potencial para sua produção sob hidroponia.

Palavras-chave: modelagem, matéria seca, estufa plástica
\end{abstract}

\section{INTRODUCTION}

Vegetable species seed production can generate expressive benefits to the grower as compared to other crops, due to intensive labor with its intrinsic social contribution on benefit distribution. Seed production of lettuce and other vegetable species, depends upon specific environmental conditions, and this is associated with the need for importing seeds. Temperature plays an important role in lettuce flowering and values above $20^{\circ} \mathrm{C}$ are ideal for stimulating panicle growth (Viggiano, 1990).

Protected environments using plastic cover allow for the control of the meteorological variables, and among these is the temperature (Frisina \& Escobedo, 1999), which increased within certain limits, accelerate plant development, reducing the length of its life cycle. Air temperature is one of the regressive variables mostly used in models to predict temporal variation in dry matter accumulation of several species, including lettuce, due to 
the ease with which it is measured and its good relationship with the amount of photosynthetically active radiation needed for the plant to complete its life cycle. Air temperature in the form of thermal units $\left({ }^{\circ} \mathrm{C}\right.$ day) is useful because of its independence of location and planting dates, being a more efficient life cycle timer than calendar days (Silva et al., 1999).

Other benefits for lettuce seed production in controlled environments, besides higher air temperatures are: protection from rain and wind during seed maturation, cultivation in the absence of weeds, physical barrier against pollinating insects and an almost complete control of plant nutrition during growth. Nutrient solutions are in rich nitrate, which may accumulate in plant tissues and cause harm for human health. On the other hand, high levels of nitrates in nutrient solution may increase seed protein concentration and physiological quality (Bewley \& Black, 1994). For these reasons, if hydroponics cultivation under controlled environments can maximize plant growth more easily than under field conditions, it can also be expected to maximize lettuce seed production and quality.

Non-linear growth models represented by sigmoid curves through the use of parts of the cosine mathematic model have been suggested as they are simple and better known than the ones normally used in modeling crop growth. The objective of this research was to propose models for lettuce growth under protected cultivation that allow for estimation of dry matter accumulation, to determine periods of maximum dry matter accumulation rate; to determine flowering as a function of climatic parameters; and to verify the technical viability of lettuce seed production under hydroponics.

\section{MATERIAL AND METHODS}

Two experiments were set up in hydroponics, under protected environment in a $10 \times 25 \times 0.0002 \mathrm{~m}$ polyvinyl cover greenhouse, at Santa Maria, State of Rio

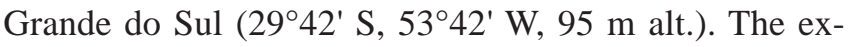
periment consisted of ten hydroponics workbenches with 'Vera' lettuce, grown in nutrient solution according to the technique proposed by Castellane \& Araújo (1995). Two of the hydroponics workbenches consisted of 12 small channels ( $0.05 \mathrm{~m}$ wide and $0.025 \mathrm{~m}$ deep) and were used as nursery to produce 936 seedlings, spaced $0.10 \times 0.10$ $\mathrm{m}$ ( $1^{\text {st }}$ transplant); four workbenches with six medium channels ( $0.10 \mathrm{~m}$ wide and $0.043 \mathrm{~m}$ deep) were used in the vegetative stage, to produce 576 plants spaced 0.25 $\times 0.25 \mathrm{~m}\left(2^{\text {nd }}\right.$ transplant $)$; and four workbenches with six large size channels each ( $0.16 \mathrm{~m}$ wide and $0.075 \mathrm{~m}$ deep) were used for the reproductive stage, to produce 288 plants, spaced $0.50 \mathrm{~m}$ within channels and 0.25 between channels ( $3^{\text {rd }}$ transplant).
Leaf dry matter $\left(L D M_{j}\right)$ and total dry matter $\left(T D M_{j}\right)$ yields were determined in 4-plant samplings during the growth period. Sampling intervals were different, with increasing frequencies up to the maximum growth, proportional to plant development, that is, sampling frequency was lower at the initial and final plant stages (slow or no growth), and higher during the intermediate plant stages (fast and maximum growth).

The number of seeds per plant was evaluated in the remaining plants from all plots in the end of plant cycle. Fifty-three plants were collected at the end of the spring experiment and 27 in the autumn. From each experiment, samples were collected at two seed maturity stages: plants with $50 \%$ and $100 \%$ of mature achenes. For both experiments, the relative total dry matter yield was calculated for the $j$ days after transplanting (DAT) $\left(R T D M_{j}\right)$, as follows:

$$
R T D M j=\frac{T D M j}{T D M_{n}}
$$

where: $T D M_{j}=$ average total dry matter of four plants on the $j^{\text {th }}$ DAT; $T D M_{n}=$ average total dry matter of four plants on the $n^{\text {th }}$ (last) day of sampling.

The relative leaf dry matter $\left(R L D M_{j}\right)$ yield on the $j^{\text {th }}$ day after transplanting (DAT) sampling was calculated as follows:

$$
R L D M j=\frac{L D M j}{L D M_{\max }}
$$

where: $L D M_{j}=$ average leaf dry matter of four plants in the $j^{\text {th }}$ DAT; $L D M_{\max }=$ average maximum leaf dry matter of four plants observed during the lettuce cycle.

Air temperature and relative humidity in the protected environment were registered daily, using a Fisher thermo-hygrograph (Fienwerk Technik, Drebach, Erzgeb, Germany). The mean daily air temperature $\left({ }^{\circ} \mathrm{C}\right)$ was calculated as:

$$
\bar{T}_{j}=\frac{T_{\max _{j}}+T_{\min _{j}}}{2}
$$

where, $\bar{T}_{j}$ refers to the average daily air temperature $\left({ }^{\circ} \mathrm{C}\right)$ on the $j^{\text {th }}$ DAT $(j=1,2, \ldots, 118$ days, for the spring-experiment; and $j=1,2, \ldots, 153$ days, for the autumn-experiment); $\operatorname{Tmax}_{\dot{j}}$ refers to the maximum air temperature $\left({ }^{\circ} \mathrm{C}\right)$ on the $j^{\text {th }}$ DAT; and $\operatorname{Tmin}_{i}$, to the minimum air temperature $\left({ }^{\circ} \mathrm{C}\right)$ on the $j^{\text {th }}$ DAT (Table 1 ).

With the average daily air temperature values $\left(\bar{T}_{j}\right)$ from the first to last day of sampling for the two experiments, the thermal index or caloric sum was calculated (degree-days - DDn) (Gilmore \& Rogers, 1958): 
Table 1 - Seeding and transplant dates (STD), number of days after transplant (DAT), number of samples (n) and sampling frequency (Fi, \%) for each time interval in the two experiments (Spring, 2001 and Autumn, 2002) of a hydroponics lettuce protected cultivation. Santa Maria, Rio Grande do Sul State, Brazil.

\begin{tabular}{|c|c|c|c|c|}
\hline STD & DAT & Description & $\mathrm{n}$ & $\mathrm{Fi}$ \\
\hline & Days & & & $\%$ \\
\hline \multicolumn{5}{|c|}{ Spring } \\
\hline Aug 15 - Sep 6, 2001 & - & Seeds up to seedlings in trays & 0 & - \\
\hline Sep 7 - Sep 19, 2001 & $1-13$ & Two- leaf plants in nursery & 3 & 23.08 \\
\hline Sep 20 - Oct 22, 2001 & $14-46$ & Medium size channels workbench & 16 & 50.00 \\
\hline \multirow[t]{2}{*}{ Oct 23/2001 - Jan 02/2002 } & $47-118$ & Large size channels workbench & 23 & 32.39 \\
\hline & & Total & 42 & 35.59 \\
\hline \multicolumn{5}{|c|}{ Autumn } \\
\hline Apr 3 - Apr 25, 2002 & - & Seeds up to seedlings in nursery & 0 & - \\
\hline Apr 26 - May 3, 2002 & $1-8$ & Two- leaf plants in nursery & 3 & 37.50 \\
\hline May 4 - Jun 6, 2002 & $9-42$ & Medium size channels workbench & 17 & 51.52 \\
\hline \multirow[t]{2}{*}{ Jun 7 - Sep 25, 2002} & $43-153$ & Large size channels workbench & 26 & 23.64 \\
\hline & & Total & 46 & 30.07 \\
\hline
\end{tabular}

$$
D D_{n}=\sum_{j=1}^{n}\left(\bar{T}_{j}-T_{B I}\right)
$$

where, $T_{B I}=$ lower base temperature $\left(T_{B I}=10^{\circ} \mathrm{C}\right)$.

For calculation purposes, when the lettuce lower base temperature $\left(\mathrm{T}_{\mathrm{BI}}=10^{\circ} \mathrm{C}\right)$ was higher than the average daily air temperature on any of the $j$ days, then, $\bar{T}_{j}$ was considered equal to $\mathrm{T}_{\mathrm{BI}}\left(\bar{T}_{j}=T_{B \mathrm{I}}\right)$.

The global solar radiation was also monitored in the protected environment at 5-minute intervals using two light-sensors (Quantum Sensor LI-190SA and Photometric Sensor LI-210SA, Li-Cor, Inc./USA) coupled to a data-logger placed on the workbench, on $1.5 \mathrm{~m}$ high. The integral of incoming solar radiation during the day was calculated for the two experiments, and photosynthetically active radiation $\left(I P A R_{j}\right)$ on the $j^{\text {th }}$ day of sampling, calculated as follows (Varlet-Grancher et al., 1989):

$$
I P A R_{j}=0.45 \cdot G R_{j}
$$

where: $I P A R_{j}=$ incoming photosynthetically active radiation $\left(\mathrm{MJ} \mathrm{m}^{-2} \mathrm{~d}^{-1}\right) ; j=1,2, \ldots, 118$ days, in the spring experiment; and $j=1,2, \ldots, 153$ days, in the autumn-experiment; and $G R_{j}=$ integral calculus of the global solar radiation values obtained at 5-minute intervals during the $j$ DAT (MJ m $\left.{ }^{-2} \mathrm{~d}^{-1}\right)$. Relative plant development $(R D)$ of lettuce under protected cultivation was calculated using varying growth periods, from the first DAT to the physiological maturity point, for both experiments, as a function of: (i) $R D(D D)_{j}=f$ (accumulated degree-days, ${ }^{\circ} \mathrm{C}$ day); (ii) $R D(G R)_{j}=f$ (accumulated incident global radia-

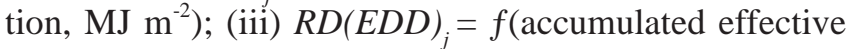
degree-days); and (iv) $R D(E D D m)_{j}=f($ modified accumulated effective degree-days).
The relative development $(R D)$ of lettuce under protected cultivation was calculated as a function of accumulated degree-days according to the following equation (considering $T_{B I}>\bar{T}_{j}$, thus, $T_{B I}=\bar{T}_{j}$ ) (Pimenta et al., 1999):

$$
R D_{(D D) j}=\sum_{j=1}^{n}\left(\bar{T}_{j}-T_{B I}\right) / D D_{f m p}, \text { with } T_{B I} \leq \bar{T}_{j}
$$

where: $R D(D D)_{j}=$ relative development on the $j^{\text {th }} \mathrm{DAT}$, as a function of the effective degree-days; $\bar{T}_{j}=$ mean daily air temperature $\left({ }^{\circ} \mathrm{C}\right) ; D D_{f m p}=$ thermal index or caloric sum of the protected lettuce cultivation at the physiological maturity point ( ${ }^{\circ} \mathrm{C}$ day); $T_{B I}$ = lettuce lower base temperature $=10^{\circ} \mathrm{C}$ (Brunini, 1976).

Lettuce relative development as a function of the incident global solar radiation inside the protected environment was obtained by the following equation:

$$
D D_{(G R) j}=\int_{t=1}^{t=n} G R_{j} / G R_{f m p} \text {, with } 0 \leq R D_{(G R) j} \leq 1(7)
$$

where, $D D(G R)_{j}$ refers to the relative lettuce development in the $j^{\text {th }} \mathrm{DAT}$, as a function of the incoming global solar radiation inside the protected environment; $\int_{t=1}^{t=n} G R_{j}$ refers to the incoming global solar radiation during ${ }^{t=1}$ the $j^{\text {th }}$ day; GR fmp, to the sum of the incident global solar radiation ( $\mathrm{MJ} \mathrm{m}^{-2}$ ) up to the physiological maturity point.

The relative development as a function of the accumulated effective degree-days was obtained by the equation:

$$
\begin{aligned}
& R D_{(E D D)_{j}}=\left[1 /\left\{\left[1 /\left(\sum_{j=1}^{n}\left(\bar{T}_{j}-T_{B I}\right)\right]+g *\left(1 / I P A R_{j}\right)\right\}\right] / E D D_{i m p}\right. \\
& \text { with } 0 \leq \mathrm{RD}_{(E D D) j} \leq 1
\end{aligned}
$$


where, $R D(E D D)_{j}=$ relative development on the $j^{\text {th }}$ DAT, as a function of the effective degree-days (Scaife et al., 1987); $\bar{T}_{j}=$ mean daily air temperature $\left({ }^{\circ} \mathrm{C}\right)$ on the $j^{\text {th }}$ DAT; $T_{B I}=$ lettuce lower base temperature $\left(10^{\circ} \mathrm{C}\right) ; I P A R_{j}$ $=$ incoming photosynthetically active radiation the $j^{\text {th }}$ DAT $\left(\mathrm{MJ} \mathrm{m}^{-2} \mathrm{~d}^{-1}\right) ; E D D_{f m p}=$ accumulated effective degree-days up to the physiological maturity point $\left({ }^{\circ} \mathrm{C}\right.$ day); $\mathrm{g}=\mathrm{a}$ constant for the species, referring to the relative effect of light and air temperature $=0.9^{\circ} \mathrm{C}$ day $\mathrm{m}^{-2} \mathrm{MJ}^{-1}$ for lettuce, according to Scaife et al. (1987), which corresponds to approximately $47 \%$ and $61 \%$ of the solar radiation and air temperature, respectively, from the total EDD.

The relative development was also calculated as a function of the modified accumulated effective degree-days $[R D(E D D m)]$, with g values different from 0.09 (Scaife et al., 1987) only for the reproductive stage, since there is no available estimate for this constant at this stage, as follows: (i) $R D(E D D m, \mathrm{~g}=0.91)$, for $\mathrm{g}=0.91(53 \%$ and $9 \%$ of the solar radiation and temperature, respectively, from the total $E D D m$ ), that is, the g value was 0.09 for the calculation of the relative development in the vegetative stage and 0.91 for the reproductive stage. This means that the effective change in EDD at the reproductive stage is due to the lower air temperature effect, evidencing the importance of air temperature when plants cover the soil completely after what, the radiation effect predominates on the relative development (Scaife, 1973; Wheeler et al., 1993 apud Ryder, 1998; Wurr \& Fellows, 1991); (ii) $R D(E D D m$, g = $0.03)_{j}$, with $g=0.03(22 \%$ and $83 \%$ of the solar radiation and temperature, respectively, from the total $E D D m$ ), that is, the $g$ value was 0.09 for the calculation of the lettuce relative development in the vegetative stage and 0.03 for the reproductive stage. This means that the opposite is simulated in relation to the previous situation. The $0^{\circ} \mathrm{C}-$ base-temperature relative developments were also calculated, considering those using degree-days.

For the evaluation of the relative plant dry mass variation with time (RTDM $)$ the following empiric model was used, as a function of degree-days, the global solar radiation, the effective degree-days and the modified effective degree-days:

$$
R T D M_{j}=\cos \left\{\frac{\pi}{2}\left(1-R D_{j}\right)\right\}
$$

where, $R D_{j}$ refers to the relative development on the $j^{\text {th }}$ DAT.

The empiric model for the evaluation of the relative leaf dry mass variation with time (RLDM), as a function of the degree-days scale, the global solar radiation, the effective degree-days and the modified effective degree-days, is given as follows:

$$
R L D M_{j}=\cos \left\{\frac{\pi}{2}\left(\frac{R D m-R D m_{j}}{R D m}\right)\right\}
$$

where, $R D m$ refers to the relative development at which leaf dry mass is maximum; and $R D m_{j}$ to the relative development on the $j^{\text {th }}$ DAT.

The empiric parameters were fit in the models so that, throughout the utilization of the experimental data, a general model for the purpose of prediction could be adjusted. Thus, the relative total plant dry mass as a function of $R D_{j}$ may be estimated by the expression:

$$
R T \hat{D} M_{j}=\cos ^{\alpha}\left\{\frac{\pi}{2}\left(1-R D_{j}\right)\right\},(\alpha \in \mathrm{R})
$$

where, $\alpha$ refers to the empiric parameter of the model (shape factor of the development curve).

The relative leaf dry mass in function of $R D(D D)_{j}$ may be estimated by the expression:

$$
R T \hat{D} M_{j}=\cos ^{\beta}\left\{\frac{\pi}{2}\left(\frac{R D m-R D_{j}}{R D m}\right)\right\},(\beta \in \mathrm{R})
$$

where, $\beta$ refers to the empiric parameter of the model (shape factor of the development curve).

The criteria adopted to the best model adjustment were: (i) assume that plant growth follows a sigmoid model, described by the dry mass accumulation over time; (ii) a significant F-test for the non-linear regression analysis; (iii) obtain the residual variance magnitude by maximum likelihood among the cosine models, characterized by different climatic variables; and (iv) point dispersion analysis in the graph.

The relative development was estimated from the derivative of the best-adjusted model, known as the maximum rate of total plant dry mass accumulation $\left(\mathrm{RD}_{\mathrm{TDMmax}}\right)$ during growth, and during flowering $\left(R D_{f l}\right)$ by the following equations (Pimenta et al., 1999):

$$
\begin{aligned}
& R \hat{D}_{\text {TDM max }}=1-\frac{2}{\pi} \operatorname{arctg}\left(\frac{1}{\sqrt{\alpha-1}}\right) \\
& R \hat{D}_{f l}=f l^{*} R D_{\text {TDM max }},(0<f l<1)
\end{aligned}
$$

where, $f l$ is the empiric conversion factor for the relative development known as the maximum rate of dry matter accumulation at flowering (first flower in 50\% plants).

The relative development was also estimated from the derivative of the best-adjusted model, known as the maximum rate of leaf dry matter accumulation $\left(\mathrm{RD}_{\text {LDMmax }}\right)$ by the following equation (Pimenta et al., 1999):

$$
R \hat{D}_{L D M \max }=R D_{m}\left[1-\frac{2}{\pi} \operatorname{arctg}\left(\frac{1}{\sqrt{\beta-1}}\right)\right]
$$




\section{RESULTS AND DISCUSSION}

The average maximum daily air temperatures were $33^{\circ} \mathrm{C}$ and $25^{\circ} \mathrm{C}$ in the spring and autumn experiments respectively. The average minimum air daily temperatures were $17^{\circ} \mathrm{C}$ and $11^{\circ} \mathrm{C}$ for the spring and autumn experiments respectively. During the vegetative and reproductive stage, average air temperature in spring were respectively $23.6^{\circ} \mathrm{C}$ and $28.3^{\circ} \mathrm{C}$ and in the autumn $17.9^{\circ} \mathrm{C}$ and $19.3^{\circ} \mathrm{C}$. The spring experiment also had more incident solar radiation (average of $13.68 \mathrm{MJ} \mathrm{m}^{-2} \mathrm{~d}^{-1}$ ) than the autumn experiment (average of $5.39 \mathrm{MJ} \mathrm{m}^{-2} \mathrm{~d}^{-1}$ ).

In the spring experiment plants completed the vegetative stage with $55.3 \%$ of the entire cycle DD (DD $\left.=977^{\circ} \mathrm{C} \mathrm{day}^{-1}\right)$ against $63.0 \%\left(\mathrm{DD}=808^{\circ} \mathrm{C}\right.$ day $\left.^{-1}\right)$ of the entire autumn cycle (Table 2). From the phenological phase of first flower up to the end of the cycle (reproductive phase), the spring experiment had $44 \%$ more accumulated degree-days than the autumn experiment.

The similarity between the degree-days in the vegetative stage in both experiments and the difference during the reproductive stage suggest that the vegetative stage needs a minimum caloric amount to be finalized, which does not seem to be valid for the reproductive stage when other factors may be more relevant. Consequently, a growth and development simulation model for lettuce from transplanting to the end of vegetative stage should take the caloric sum into consideration.

Regarding the chronological age (Table 2) the spring experiment had its vegetative stage $30 \%$ shorter (72 days) than the autumn experiment (102 days) and accumulated around $30 \%$ more TDM (45.47 $\left.\mathrm{g} \mathrm{plant}^{-1}\right)$ than in autumn (33.99 $\mathrm{g} \mathrm{plant}^{-1}$ ). The reproductive stage in the spring was $10 \%$ shorter (46 days) than that of autumn (51 days) but accumulated $35 \%$ more TDM (33.22 g plant $\left.^{-1}\right)$ than in autumn (24.52 g plant $\left.^{-1}\right)$. The TDM production cannot be dissociated between stages because photosynthesis depends on leaf area, and yield would be greater the faster the plant reached maximum leaf area index and the longer the period when leaf area is active (Pereira \& Machado, 1987).

Table 2 - Days after transplant (DAT), degree-days $\left(D_{\mathrm{i}}\right)$, relative development $\left[R D(D D)_{j}\right]$, accumulated total global solar radiation (GR), relative development $\left[R D(G R)_{j}\right]$ in function of the 'Vera' lettuce phenological stadium, grown in hydroponics under protected environment, during September $7^{\text {th }}, 2001$ to January $2^{\text {nd }}$, 2002; and April $26^{\text {th }}$, 2002 to September 25 ${ }^{\text {th }}$, 2002. Santa Maria, State of Rio Grande do Sul, Brazil.

\begin{tabular}{|c|c|c|c|c|c|}
\hline Phenological Phase & DAT & $\mathrm{DD}_{\mathrm{j}}$ & $\mathrm{RD}(\mathrm{DD})_{\mathrm{j}}$ & GR & $\mathrm{RD}(\mathrm{GR})_{\mathrm{j}}$ \\
\hline & & ${ }^{\circ} \mathrm{C}$ day & & $\mathrm{MJ} \mathrm{m}^{-2}$ & \\
\hline \multicolumn{6}{|c|}{ September $7^{\text {th }}, 2001$ to January $2^{\text {nd }}, 2002$ (Spring) } \\
\hline 2 to 5 leaves $^{1}$ & 1 to 14 & 147 & 0.083 & 155 & 0.096 \\
\hline 6 to 8 leaves & 15 to 22 & 250 & 0.141 & 235 & 0.145 \\
\hline 9 to 15 leaves & 23 to 32 & 375 & 0.212 & 330 & 0.205 \\
\hline 16 to 22 leaves & 33 to 40 & 490 & 0.277 & 437 & 0.271 \\
\hline 23 to 30 leaves $^{2}$ & 41 to 54 & 706 & 0.399 & 638 & 0.395 \\
\hline Flowering start $^{3}$ & 55 to 72 & 977 & 0.553 & 912 & 0.565 \\
\hline First flower & 73 to 92 & 1316 & 0.744 & 1181 & 0.732 \\
\hline Plant with $50 \%$ of open flowers ${ }^{4}$ & 93 to 99 & 1443 & 0.816 & 1286 & 0.797 \\
\hline Plant with $100 \%$ of open flowers & 100 to 112 & 1689 & 0.929 & 1501 & 0.930 \\
\hline Plant with $50 \%$ of mature achenes & 113 to 117 & 1797 & 0.989 & 1594 & 0.987 \\
\hline Plant with $100 \%$ of mature achenes & 118 & 1817 & 1 & 1614 & 1 \\
\hline \multicolumn{6}{|c|}{ April $26^{\text {th }}, 2002$ to September $25^{\text {th }}, 2002$ (Autumn) } \\
\hline 2 to 5 leaves $^{1}$ & 1 to 14 & 141 & 0.011 & 72 & 0.087 \\
\hline 6 to 8 leaves & 15 to 20 & 224 & 0.175 & 103 & 0.125 \\
\hline 9 to 15 leaves & 21 to 32 & 340 & 0.265 & 155 & 0.189 \\
\hline 16 to 22 leaves & 33 to 52 & 497 & 0.388 & 222 & 0.270 \\
\hline 23 to 30 leaves $^{2}$ & 53 to 66 & 572 & 0.446 & 292 & 0.355 \\
\hline Flowering start $^{3}$ & 67 to 102 & 808 & 0.630 & 447 & 0.543 \\
\hline First flower & 103 to 125 & 1058 & 0.825 & 584 & 0.708 \\
\hline Plant with $50 \%$ of open flowers ${ }^{4}$ & 126 to 132 & 1116 & 0.871 & 639 & 0.755 \\
\hline Plant with $100 \%$ of open flowers & 133 to 140 & 1175 & 0.917 & 699 & 0.848 \\
\hline Plant with $50 \%$ of mature achenes & 141 to 152 & 1272 & 0.993 & 810 & 0.983 \\
\hline Plant with $100 \%$ of mature achenes & 153 & 1282 & 1 & 824 & 1 \\
\hline
\end{tabular}

${ }^{1}$ The two first cotyledon leaves were not included in the leaf number; and the counted leaves were longer than $5 \mathrm{~cm}$.

${ }^{2}$ From the stage of 23 to 30 leaves, and after, the product was considered inappropriate for commercialization due to the lactucine exudation, which confers a bitter taste to the lettuce.

${ }^{3}$ From the flowering stage and on, all other phases are referred, approximately, to the first day of the respective DAT interval.

${ }^{4}$ The phase of $50 \%$ open flowers and others are known as $50 \%$ of plants in such phenological stage. 
The vegetative stage, in which a large portion of the lettuce dry matter is produced (mainly leaves), present higher or lower efficiency in dry matter accumulation depending on the available active photosynthetic radiation and of plant $\mathrm{CO}_{2}$ fixation ability, which occurs more efficiently in the warm season (Andriolo, 1999). Thus, in spring, with more solar radiation, plants accumulated more dry matter than in autumn, and this was also reflected in the reproductive phase.

During the reproductive phase there is a linear reduction in leaf dry mass, since assimilates are exported to other plant organs. Thus, an interference of other factors besides air temperature is expected, resulting in variation of the total dry matter production. This variability, therefore, depends on leaf dry matter accumulation during the vegetative phase and on root and leaf senescence. Considering that light saturation was easier in spring than in autumn, it can be concluded that temperatures do affect dry matter accumulation during the spring. In the autumn, with a more constant and lower level of solar radiation, interactions should be more complex.

In the autumn experiment plants completed the vegetative stage with a $G R$ of $447 \mathrm{MJ} \mathrm{m}^{-2}$ (54.3\% of total cycle) whereas in spring, this stage was completed with a GR of $912 \mathrm{MJ} \mathrm{m}^{-2}$ (56.5\% of total cycle) (Table 2). During the reproductive stage (from first flower up to $100 \%$ mature achenes), the spring experiment received $45 \%$ more solar radiation than the autumn experiment. Even with solar radiation values below the minimum limit for vegetables growth (8.4 $\mathrm{MJ} \mathrm{m}^{-2} \mathrm{~d}^{-1}$; FAO, 1990), lettuce in protected environment finishes its life cycle as pointed out by Caron (2002).

A stronger dissociation between air temperature and solar radiation was observed under protected environment than in the open field, hence, in this condition even with temperatures close to the ideal in the colder season, the lower light intensity limits dry matter accumulation in the same levels than in other seasons with higher solar radiation, thus delaying crop cycle.

Regarding the growth models, a temporal variation in dry matter accumulation in hydroponics lettuce is probably best explained by the relative growth and development as a function of degree-days sum and/or the interaction between degree-days and solar radiation. Considering the climatic variation between the experiments both higher solar radiation incidence and average temperatures during spring contributed to larger TDM accumulation and crop cycle shortness, the latter having a greater impact on the vegetative stage.

By using temperature and solar radiation to characterize relative development as a function of the effective degree-days (EDD), it becomes evident that in the spring experiment, plants completed their vegetative stage with $53.8 \%\left(\mathrm{EDD}=776^{\circ} \mathrm{C}\right.$ day) of the total EDD versus $61.0 \%\left(\mathrm{EDD}=532^{\circ} \mathrm{C}\right.$ day $)$ of the total EDD in the au- tumn (Table 3). The spring experiment had 49\% more effective degree-days accumulated than the autumn experiment.

The relative development was practically the same when DD was used and also very close with the $R D(E D D m, g=0.03)_{j}$. However, during the vegetative period there were changes in the relative development quantification: in the spring experiment plants completed their vegetative cycle with $76.3 \%\left(776^{\circ} \mathrm{C}\right.$ day) of the total $E D D m$ cycle against $81.5 \%\left(532^{\circ} \mathrm{C}\right.$ day) in the autumn cycle.

During the reproductive phase, the spring experiment showed 50\% more modified accumulated degreedays than in the autumn, with similar results between seasons (periods) when comparing $D D$ and $E D D$. Hence, the inclusion of solar radiation (in relation of the use of $D D$ ) and the reduction in the relative weight of air temperature variable during reproductive phase (in relation to $E D D$ and $E D D m, \mathrm{~g}=0.03$ ) led to a better characterization of the relative development with the use of $R D(E D D m$, $\mathrm{g}=0.91)_{i}$.

In the spring experiment, the best fit model, using the criteria of the average least error mean square (Table 4) and the point dispersion around the total dry matter variation curve, was calculated with $R D(E D D m, \mathrm{~g}=0.91)_{\mathrm{i}}$ (Figure 1a), but without significant differences to the other regressive variables used in the model. The development characterization as already cited by several authors (Scaife, 1973; Wheeler et al., 1993 cited by Ryder, 1998; Wurr \& Fellows, 1991), confirm that during the vegetative phase, temperature is the most important factor for dry matter accumulation followed by solar radiation.

In the autumn experiment, considering the least error mean square (Table 4 ) and the dispersion of points, the $R T D M_{j}$ estimation was calculated with $R D(E D D m$, with $\left.\mathrm{T}_{\mathrm{BI}}=0, \mathrm{~g}=0.91\right)_{\mathrm{i}}$ (Figure $1 \mathrm{c}$ ), that differed at $5 \%$ in relation to the adjustment by $R D(E D D m, \mathrm{~g}=0.91)_{\mathrm{j} .}$. In this low solar radiation season, as already discussed, the interaction between air temperature and solar radiation explains dry matter accumulation better and reinforces the importance of temperature during vegetative stage and solar radiation during reproductive stage.

The fact that base temperatures below $10^{\circ} \mathrm{C}$ were not used gave to the regression variables a better fit, under the least error mean square (Table 4). In the autumn experiment, with lower daily average temperatures, there were significant differences for regressive variables with the use of base temperatures below $10^{\circ} \mathrm{C}$, which means that during periods with temperatures below $10^{\circ} \mathrm{C}$ there still is growth under hydroponics. This may be due to the fact that in higher plants physiological processes occur in a large range of air temperatures $\left(0\right.$ a $40^{\circ} \mathrm{C}$ ) (Silva et al., 1999). Wurr et al. (1992), using the Gompertz and logistic models to estimate lettuce dry matter production also got better fit with lower base temperature of $0^{\circ} \mathrm{C}$. 
Table 3 - Day intervals after transplant (DAT), accumulated effective degree-days ( $E D D)$ and the respective lettuce relative development $\left[R D(E D D)_{i}\right]$; modified accumulated effective $(E D D m)$ and the respective lettuce relative development when $\mathrm{g}=0.91\left[R D(E D D m, \mathrm{~g}=0.91)_{\mathrm{j}}\right]$; modified accumulated effective degree-days $(E D D m)$ and the respective lettuce relative development when $\mathrm{g}=0.03\left[R D(E D D m, \mathrm{~g}=0.03)_{\mathrm{j}}\right]$, as a function of the lettuce phenological phase, 'Vera' variety grown in hydroponics under protected cultivation. 2001/2002. Santa Maria, RS, Brazil.

\begin{tabular}{|c|c|c|c|c|c|c|c|}
\hline Phenological Phase & DAT & $E D D$ & $\mathrm{RD}(E D D)^{\mathrm{j}}$ & $E D D m^{(2)}$ & $\begin{array}{c}\mathrm{RD}(E D D m \\
\mathrm{g}=0.91)_{\mathrm{j}}\end{array}$ & $E D D m^{(3)}$ & $\mathrm{RD}(E D D m, \mathrm{~g}=0.03)_{\mathrm{j}}$ \\
\hline \multicolumn{8}{|c|}{ September $7^{\text {th }}, 2001$ to January $2 n^{\text {d, }} 2002$ (Spring) } \\
\hline 2 to 5 leaves $^{1}$ & 1 to 14 & 119 & 0.082 & 119 & 0.117 & 119 & 0.077 \\
\hline 6 to 8 leaves & 15 to 22 & 199 & 0.138 & 199 & 0.196 & 199 & 0.129 \\
\hline 9 to 15 leaves & 23 to 32 & 297 & 0.206 & 297 & 0.292 & 297 & 0.192 \\
\hline 16 to 22 leaves & 33 to 40 & 389 & 0.270 & 389 & 0.382 & 389 & 0.251 \\
\hline 23 to 30 leaves ${ }^{2}$ & 41 to 54 & 560 & 0.388 & 560 & 0.550 & 560 & 0.362 \\
\hline Flowering start ${ }^{3}$ & 55 to 72 & 776 & 0.538 & 776 & 0.763 & 776 & 0.502 \\
\hline First flower & 73 to 92 & 1038 & 0.720 & 869 & 0.854 & 1084 & 0.700 \\
\hline Plant with $50 \%$ open flowers ${ }^{4}$ & 93 to 99 & 1139 & 0.790 & 905 & 0.890 & 1201 & 0.776 \\
\hline Plant with $100 \%$ open flowers & 100 to 112 & 1337 & 0.928 & 978 & 0.962 & 1428 & 0.923 \\
\hline Plant with $50 \%$ mature achenes & 113 to 117 & 1425 & 0.989 & 1010 & 0.993 & 1529 & 0.988 \\
\hline Plant with $100 \%$ mature achenes & 118 & 1441 & 1.000 & 1017 & 1.000 & 1547 & 1.000 \\
\hline \multicolumn{8}{|c|}{ April $26^{\text {th }}, 2002$ to September $25^{\text {th }}, 2002$ (Autumn) } \\
\hline 2 to 5 leaves $^{1}$ & 1 to 14 & 93 & 0.107 & 93 & 0.143 & 93 & 0.099 \\
\hline 6 to 8 leaves & 15 to 20 & 142 & 0.163 & 142 & 0.218 & 142 & 0.151 \\
\hline 9 to 15 leaves & 21 to 32 & 216 & 0.248 & 216 & 0.331 & 216 & 0.229 \\
\hline 16 to 22 leaves & 33 to 52 & 308 & 0.353 & 308 & 0.472 & 308 & 0.326 \\
\hline 23 to 30 leaves $^{2}$ & 53 to 66 & 365 & 0.418 & 365 & 0.559 & 365 & 0.387 \\
\hline Flowering start ${ }^{3}$ & 67 to 102 & 532 & 0.610 & 532 & 0.815 & 532 & 0.564 \\
\hline First flower & 103 to 125 & 701 & 0.804 & 582 & 0.892 & 744 & 0.789 \\
\hline Plant with $50 \%$ open flowers ${ }^{4}$ & 126 to 132 & 746 & 0.855 & 600 & 0.919 & 796 & 0.844 \\
\hline Plant with $100 \%$ open flowers & 133 to 140 & 791 & 0.907 & 617 & 0.946 & 849 & 0.900 \\
\hline Plant with $50 \%$ mature achenes & 141 to 152 & 863 & 0.990 & 649 & 0.994 & 934 & 0.990 \\
\hline Plant with $100 \%$ mature achenes & 153 & 872 & 1.000 & 653 & 1.000 & 943 & 1.000 \\
\hline
\end{tabular}

${ }^{1}$ The two first cotyledon leaves were not included in the leaf number; and the counted leaves were longer than $5 \mathrm{~cm}$.

${ }^{2}$ Modified accumulated effective with $\mathrm{g}=0.09$ from the first phase up to the flowering starting, including it (vegetative phase); and, 0.91 from the first flower phase up to the last phase, including it (reproductive phase).

${ }^{3}$ Modified accumulated effective with $\mathrm{g}=0.09$ from the first phase up to the flowering starting, including it (vegetative phase); and, 0.03 from the first flower phase up to the last phase, including it (reproductive phase).

${ }^{4}$ From the phase of 23 to 30 leaves, and after, the product was considered improper for commercialization due to the lactucine exudation, what confers a bitter taste to the lettuce.

${ }^{5}$ From the flowering stadium and after, all other phases are referred, approximately, to the first day of the respective DAT interval.

${ }^{6}$ The phase of $50 \%$ open flowers and others are known as $50 \%$ of plants in such phenological.

In the spring experiment, the best fit by the least error mean square criterion (table 4) and point dispersion to estimate $R L D M_{i}$ using $R D\left(D D \text { with } \mathrm{T}_{\mathrm{IB}}=0\right)_{\mathrm{j}}$ (Figure $1 \mathrm{~b}$ ), although with no differences for the other regressive variable used in the model. LDM accumulation occurs mainly during the vegetative stage, hence, under high solar radiation, air temperature explains dry mass variation better.

In the autumn experiment the best fit through the least error mean square criterion (Table 4) and point dispersion to estimate $R L D M_{j}$ was with the variable $\mathrm{RD}\left(\mathrm{EDDm} \text { with } \mathrm{T}_{\mathrm{IB}}=0, \mathrm{~g}=0.91\right)_{\mathrm{j}}$ (Figure $1 \mathrm{~d}$ ), which differed in relation to other models $(P<0.05)$. Under low radiation the interaction effect between temperature and radiation explains the $L D M$ accumulation better, and again, air temperature was more important in the vegeta- tive stage than in the reproductive one. The $G R$ was the sole regression variable in all tested situations that did not fit the cosine model to $R L D M_{j}$ estimation (Table 4).

From the derivative of the best fit model by the least error mean square and smaller data dispersion around the curve for the $R T D M_{i}$, the relative development of lettuce crop was estimated as to the maximum rate of total dry matter accumulation and for the flowering in spring: $R D(E D D m, g=0.91)=f($ modified effective degree-days, $g=0.91$ in the reproductive phase): $R \hat{D} T D M \max =0.6187$; and, $f l=1.243$; and autumn: $R D\left(E D D m \text { with } \mathrm{T}_{\mathrm{IB}}=0, \mathrm{~g}=0.91\right)_{\mathrm{j}}=f($ modified effective degree-days, with $\mathrm{T}_{\mathrm{IB}}=0, \mathrm{~g}=0.91$ in the reproductive phase): $R \hat{D} T D M \max =0.6661$; and $f l=1.296$.

From the derivative of the best fit model by the least error mean square and smaller data dispersion 


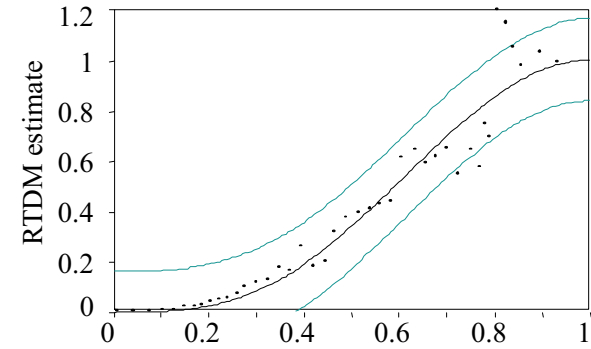

A

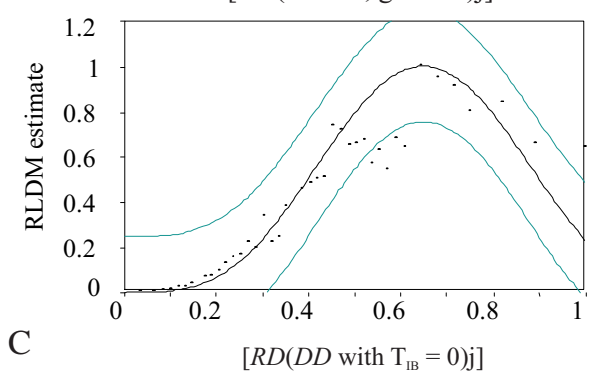

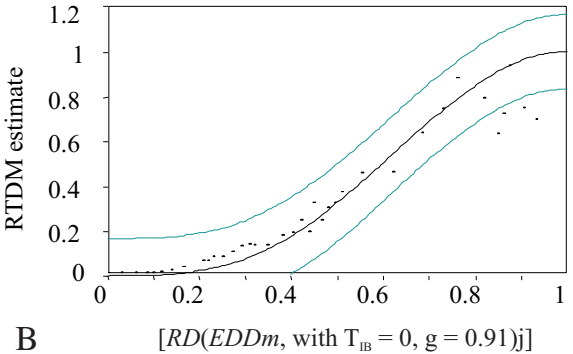

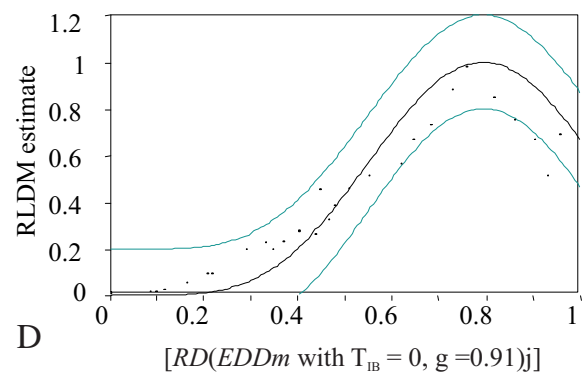

Figure 1 - Cosine model $90 \%$ confidence interval for the estimation of lettuce relative total dry matter ( $R T D M j)$ production related to the relative development as a function of (a) modified effective degree-days $[R D(E D D m, g=0.91)$ ] $]$ in the spring experiment; and in the autumn experiment, (b) by modified effective $\left[R D\left(E D D m \text { with } \mathrm{T}_{\mathrm{IB}}=0, \mathrm{~g}=0.91\right)_{\mathrm{j}}\right]$. For the relative leaf dry matter $(R L D M j)$ in the spring (c) by $\left[R D(D D) \text { with } \mathrm{T}_{\mathrm{IB}}=0\right)_{\mathrm{j}}$; ; and in the autumn (d) by modified effective $\left[R D\left(E D D m \text { with } \mathrm{T}_{\mathrm{IB}}=0, \mathrm{~g}=0.91\right)_{\mathrm{j}}\right]$.

Table 4 - Error mean squares of cosine models adjusted to regressive variables: $R D(D D)_{j,} R D(G R)_{j}, R D(E D D)_{j}$ and $R D(E D D m)_{j}$, in two experiments (Spring and Autumn) for the estimates of relative leaf and total dry matter yields. Santa Maria, RS, Brazil.

\begin{tabular}{|c|c|c|}
\hline Regressive variable & $R \hat{T D} M_{j}$ & $R \hat{L D} M_{j}$ \\
\hline \multicolumn{3}{|l|}{ Spring experiment (September $7^{\text {th }}, 2001$ to January $2^{\text {nd }}, 2002$ ) } \\
\hline$R D(D D)_{\mathrm{j}}=f($ degree-days $)$ & $0.0126 \mathrm{a}^{2}$ & $0.0225 \mathrm{a}$ \\
\hline$R D\left(D D \text { with } \mathrm{T}_{\mathrm{IB}}=0^{3}\right)_{\mathrm{j}}=f\left(\right.$ with $\left.\mathrm{T}_{\mathrm{IB}}=0\right)$ & $0.0120 \mathrm{a}$ & $0.0216 \mathrm{a}$ \\
\hline$R D(G R)_{\mathrm{j}}=f($ global radiation $)$ & $0.0116 \mathrm{a}$ & $0.0217 \mathrm{a}$ \\
\hline$R D(E D D)_{\mathrm{j}}=f($ effective $)$ & $0.0128 \mathrm{a}$ & 0.0228 a \\
\hline$R D\left(E D D \text { with } \mathrm{T}_{\mathrm{IB}}=0\right)_{\mathrm{j}}=f\left(\right.$ effective, with $\left.\mathrm{T}_{\mathrm{IB}}=0\right)$ & $0.0123 \mathrm{a}$ & 0.0222 a \\
\hline$R D\left(E D D m \mathrm{~g}^{4}=0.91\right)_{\mathrm{j}}=f($ modified effective, $\mathrm{g}=0.91$ in reproductive stage $)$ & $0.0093 \mathrm{a}$ & $0.0260 \mathrm{a}$ \\
\hline$R D(E D D m \quad \mathrm{~g}=0.03)_{\mathrm{j}}=f($ modified effective, $\mathrm{g}=0.03$ in reproductive stage $)$ & 0.0142 a & $0.0241 \mathrm{a}$ \\
\hline$R D\left(E D D m \text { with } \mathrm{T}_{\mathrm{IB}}=0, \mathrm{~g}=0.91\right)_{\mathrm{j}}=f\left(\right.$ modified effective with $\mathrm{T}_{\mathrm{BI}}=0, \mathrm{~g}=0.91$ in reproductive stage $)$ & $0.0104 \mathrm{a}$ & $0.0284 \mathrm{a}$ \\
\hline$R D\left(E D D m \text { with } \mathrm{T}_{\mathrm{IB}}=0, \mathrm{~g}=0.03\right)_{\mathrm{j}}=f\left(\right.$ modified effective with $\mathrm{T}_{\mathrm{BI}}=0, \mathrm{~g}=0.03$ in reproductive stage $)$ & 0.0142 a & 0.0239 a \\
\hline EMSaverage & $0.0122 \mathrm{~A}$ & $0.0237 \mathrm{~A}$ \\
\hline \multicolumn{3}{|l|}{ April $26^{\text {th }}, 2002$ to September $25^{\text {th }}, 2002$ (Autumn) } \\
\hline$R D(D D)_{\mathrm{j}}=f($ degree-days $)$ & $0.0117 \mathrm{ab}$ & $0.0321 \mathrm{~b}$ \\
\hline$R D\left(D D \text { with } \mathrm{T}_{\mathrm{IB}}=0^{3}\right)_{\mathrm{j}}=f\left(\right.$ with $\left.\mathrm{T}_{\mathrm{IB}}=0\right)$ & 0.0098 a & $0.0267 \mathrm{~b}$ \\
\hline$R D(G R)_{\mathrm{j}}=f($ global radiation $)$ & $0.0114 \mathrm{ab}$ & - \\
\hline$R D(E D D)_{\mathrm{j}}=f($ effective $)$ & $0.0116 \mathrm{ab}$ & $0.0315 \mathrm{~b}$ \\
\hline$R D\left(E D D\right.$ with $\left.\mathrm{T}_{\mathrm{IB}}=0\right) \mathrm{j}=f\left(\right.$ effective, with $\left.\mathrm{T}_{\mathrm{IB}}=0\right)$ & $0.0098 \mathrm{a}$ & $0.0282 \mathrm{~b}$ \\
\hline$R D\left(E D D m \mathrm{~g}^{4}=0.91\right)_{\mathrm{j}}=f($ modified effective, $\mathrm{g}=0.91$ in reproductive stage $)$ & $0.0161 \mathrm{~b}$ & $0.0265 \mathrm{~b}$ \\
\hline$R D(E D D m \quad \mathrm{~g}=0.03)_{\mathrm{j}}=f($ modified effective, $\mathrm{g}=0.03$ in reproductive stage $)$ & $0.0134 \mathrm{ab}$ & $0.0375 \mathrm{~b}$ \\
\hline$R D\left(E D D m \text { with } \mathrm{T}_{\mathrm{IB}}=0, \mathrm{~g}=0.91\right)_{\mathrm{j}}=f\left(\right.$ modified effective with $\mathrm{T}_{\mathrm{BI}}=0, \mathrm{~g}=0.91$ in reproductive stage $)$ & 0.0099 a & 0.0142 a \\
\hline$R D\left(E D D m \text { with } \mathrm{T}_{\mathrm{IB}}=0, \mathrm{~g}=0.03\right)_{\mathrm{j}}=f\left(\right.$ modified effective with $\mathrm{T}_{\mathrm{BI}}=0, \mathrm{~g}=0.03$ in reproductive stage $)$ & $0.0122 \mathrm{ab}$ & $0.0368 \mathrm{~b}$ \\
\hline EMS(average $)$ & $0.0118 \mathrm{~A}$ & $0.0292 \mathrm{~A}$ \\
\hline
\end{tabular}


Table 5 - Physiological quality and seed yield components (fruits) of lettuce, variety 'Vera', in hydroponics protected cultivation in the Spring (2001) and Autumn (2002) experiments, in two harvesting periods: plants with 50\% (A) and 100\% (B) of mature achenes. Santa Maria, RS, Brazil.

\begin{tabular}{|c|c|c|c|c|}
\hline \multirow{4}{*}{ Seed physiological quality variables } & \multicolumn{4}{|c|}{ Experiment } \\
\hline & \multicolumn{2}{|c|}{ Spring } & \multicolumn{2}{|c|}{ Autumn } \\
\hline & \multicolumn{2}{|c|}{ Harvest period } & \multicolumn{2}{|c|}{ Harvest period } \\
\hline & A & $\mathrm{B}$ & A & $\mathrm{B}$ \\
\hline Seed vigor:first counting ( $\%)$ & $99.5 \mathrm{a}^{1}$ & $99.5 \mathrm{a}$ & $99.8 \mathrm{a}$ & $94.3 \mathrm{a}$ \\
\hline Seed germination $(\%)$ & $99.5 \mathrm{a}$ & $99.5 \mathrm{a}$ & $99.8 \mathrm{a}$ & $94.3 \mathrm{a}$ \\
\hline Electrical condutivity $\left(\mu \mathrm{S} \mathrm{cm}^{-1} \mathrm{~g}^{-1}\right)$ & $75.8 \mathrm{a}$ & $96.4 \mathrm{~b}$ & $117.5 \mathrm{c}$ & $164.5 \mathrm{~d}$ \\
\hline Root length $(\mathrm{cm})$ & $2.8 \mathrm{a}$ & $3.0 \mathrm{a}$ & $2.1 \mathrm{~b}$ & $2.0 \mathrm{~b}$ \\
\hline 1000 achenes mass $(\mathrm{g})^{2}$ & $0.995 \mathrm{a}$ & $0.995 \mathrm{a}$ & $1.348 \mathrm{a}$ & $1.250 \mathrm{a}$ \\
\hline \multicolumn{5}{|l|}{ Yield components } \\
\hline Number of achenes per capitulum & $14.2 \mathrm{a}$ & $10.4 \mathrm{~b}$ & $10.3 \mathrm{~b}$ & $7.9 \mathrm{c}$ \\
\hline Number $\mathrm{n}^{\circ}$. of capitulum with achenes/plant & $731.2 \mathrm{a}$ & $528.1 \mathrm{~b}$ & $274.0 \mathrm{c}$ & $269.3 \mathrm{c}$ \\
\hline Seed mass/plant $(\mathrm{g})^{2}$ & $7.6 \mathrm{a}$ & $4.5 \mathrm{~b}$ & $2.6 \mathrm{c}$ & $2.1 \mathrm{c}$ \\
\hline
\end{tabular}

${ }^{1}$ Means followed by the same letters in the line, do not difer by the Student t test (0.01).

${ }^{2}$ Seed weight corrected to $6 \%$ moisture.

around the curve for the $R L D M_{\text {, }}$, the relative development expressed as leaf dry matter maximum rate for the spring experiment was estimated: $R D\left(D D \text { with } \mathrm{T}_{\mathrm{IB}}=0\right)_{\mathrm{j}}=f(\mathrm{de}-$ gree-days, with $\left.\mathrm{T}_{\mathrm{IB}}=0\right): R \hat{D}_{L D M} \max =0.4026$; and autumn: $\operatorname{Dr}\left(\mathrm{GDEm} \text { with } \mathrm{T}_{\mathrm{BI}}=0, \mathrm{~g}=0.91\right)_{\mathrm{j}}=f($ effective modified degree-day with $\mathrm{T}_{\mathrm{BI}}=0, \mathrm{~g}=0.91$ in the reproductive phase): $R \hat{D}_{L D M} \max =0.4135$.

Hydroponic lettuce seeds showed high physiological quality measured as germination and vigor tests (first counting) with no differences either between experiments (t test) or between the two harvests (plants with 50 or $100 \%$ of mature achenes) (Table 5). However, the electrical conductivity test and root length, in the spring experiment produced more vigorous seeds than those of autumn $(P<0.01)$. The harvest with 50\% mature achenes was the combination: "cultivation period-harvesting", that gave the highest average seed yield (Table 5).

The greater dry matter accumulation during the vegetative phase in the spring due to higher air temperatures and solar radiation than in the autumn has been reported for other crop species as factors leading to greater fruit number (Andriolo, 1999). The climatic condition during spring was closer to the ideal daily air temperature $\left(25^{\circ} \mathrm{C}\right)$ and also daylength $(13 \mathrm{~h})$ than in the autumn with only average seed quality production (Ryder, 1998).

The models tested can be used for the estimation of lettuce dry mass variation in a protected environment, as well as to predict periods of maximum dry mass accumulation rates and flowering, once season is taken into account .The models that best characterize growth and development are those where air temperature is most important during vegetative phase and radiation during the reproductive phase.

\section{REFERENCES}

ANDRIOLO, J.L. Fisiologia da produção de hortaliças em ambiente protegido. Horticultura Brasileira, v.18, p.26-33, 1999.
BEWLEY, J.D.; BLACK, M. Seeds: physiology of development and germination. 2.ed. New York: Plenum Press, 1994. 445p.

BRUNINI, O. Temperatura-base para alface cultivar "white boston", em um sistema de unidades térmicas. Bragantia, v.35, p.213-219, 1976.

CARON, B.O. Crescimento de alface a campo e em estufa plástica. Santa Maria: UFSM, 2002. 51p. (Tese - Doutorado).

CASTELLANE, P.D.; ARAÚJO, J.A.C. de. Cultivo sem solo: hidroponia. 4.ed. Jaboticabal: FUNEP, 1995. 43p.

FAO. Protected cultivation in the Mediterranean climate. Rome, 1990. v.1, 313p.

FRISINA, V.A.; ESCOBEDO, J.F. Balanço de radiação e energia da cultura de alface em estrutura de polietileno. Pesquisa Agropecuária Brasileira, v.34, p.1775-1786, 1999.

GILMORE , E.; ROGERS, J. S. Heat units as a method of measuring maturity in corn. Agronomy Journal, v.50, p.611-615, 1958.

PEREIRA, A.R.; MACHADO, E.C. Análise quantitativa do crescimento de comunidade vegetal. Campinas: Instituto Agronômico, 1987. 33p. (Boletim Técnico, 114).

PIMENTA, H.S.; FANCELLI, A.L.; DOURADO NETO, D. Modelo matemático para estimar o acúmulo de matéria seca e prever as épocas do florescimento e do ponto de maturidade fisiológica da cultura de feijão. Scientia Agricola, v.56, p.915-920, 1999.

RYDER, E.J. Lettuce, endive and chicory. Wallingford: CABI, 1998. 203p. SCAIFE, M.A. The early relative growth rates of six lettuce cultivars as affected by temperature. Annals of Applied Biology, v.74, p.119-128, 1973.

SCAIFE, M.A.; COX, E.F.; MORRIS, G.E.L. The relationship between shoot weight, plant density and time during the propagation of four vegetable species. Annals of Botany, v.59, p.325-334, 1987.

SILVA, E.L.; MARTINEZ, L.F.; YITAYEW, M. Relação entre coeficientes de cultura e graus-dia de desenvolvimento da alface. Horticultura Brasileira, v.17, p.134-142, 1999.

VARLET-GRANCHER C.; GOSSE, G.; CHARTIER, M.; SINOQUET, H.; BONHOMME, R.; ALLIRAND, J.M. Mise au point: rayonnement solaire absorbé ou intercepté par un courvet végétal. Agronomie, v.9, p.419439, 1989.

VIGGIANO, J. Produção de sementes de hortaliças. Jaboticabal: FCAV; FUNEP, p.61-77, 1990.

WURR, D.C.E.; FELLOWS, J.R. The influence of solar radiation and temperature on the head weight of crisp lettuce. Journal of Horticultural Science, v.66, p.183-190, 1991.

WURR, D.C.E.; FELLOWS, J.R.; HIRON, R.W.P. et al. The development and evaluation of techniques to predict when to harvest iceberg lettuce heads. Journal of Horticultural Science, v.67, p.385-393, 1992.

Received March 14, 2003

Accepted April 28, 2004 